\title{
The control of maritime traffic in the Strait of Gibraltar
}

\author{
Miguel A. Cepillo GalvíN*
}

\begin{abstract}
The control of maritime traffic in the Strait of Gibraltar is conditioned by the regulation established in the United Nations Convention on the Law of the Sea, of 1982, in relation to straits used for international navigation where transit passage is applied. In this respect, it is necessary a cooperation between Spain and Morocco in order to designate sea lanes and establish a traffic separation scheme in that space. An analysis of this cooperation and of the last modifications of the Traffic Separation Scheme of the Strait of Gibraltar after the new Tangier-Med port being brought into service will be carried out in this paper.
\end{abstract}

Keywords Strait of Gibraltar - Traffic Separation Scheme - Cooperation Hispano-Moroccan - Maritime traffic.

\section{INTRODUCTION}

The Strait of Gibraltar has undoubtedly been one of the world's main maritime shipping routes since ancient time, of great geostrategic and commercial interest. It joins two continents and, as happens with other important straits used for international navigation, was the object of special attention at the core of the III Conference of the United Nations on the Law of the Sea, which would later lead to a specific regulation for this type of spaces in the United Nations Convention on the Law of the Sea, of 1982 (UNCLOS).

On the other hand, this Strait constitutes a scene of territorial controversies between Spain and Morocco that at first may have made that the control of maritime traffic in this space more complex.

In this study, we will analyse the consequences for the Strait of Gibraltar that stem from this special treatment granted in the UNCLOS to straits used for international navigation. We will pay special attention to that referring to the navigation regime applicable to this Strait and more specifically, related to the Maritime Traffic Separation Scheme (TSS) that is currently running there and the cooperation between Spain and Morocco in this respect.

We have structured this paper into four sections. After a brief introduction in the first section, the second section will be dedicated to the classification of the Strait of Gibraltar as a strait used for international navigation in which the regime of transit passage is applied, after which we will go on in the third section to a more detailed analysis of the TSS, to then finish with some conclusions.

University of Cádiz, Spain. Email: miguel.cepillo@uca.es. Research Project Cuestiones territoriales y cooperación transfronteriza en el Área del Estrecho (DER2012-34577) of the National R+D+I, call 20I2, Ministry of Economy and Competitiveness of Spain.

I United Nations Convention on the Law of the Sea (adopted ro December 1982, entered into force 16 November 1994) 1833 United Nations Treaty Series 397. 


\section{THE STRAIT OF GIBRALTAR AS A STRAIT USED FOR INTERNATIONAL NAVIGATION}

We must bear in mind that the regimen applicable to straits used for international navigation is an important exponent of the supposed balance between the principals of freedom and appropriation pursued in the UNCLOS. ${ }^{2}$

A different question is whether this balance has been effectively achieved in virtue of the new but problematic "regime of transit passage" applicable to the main straits used for international navigation, according to that set out in Part III of the UNCLOS. This is a very complex undertaking as the straits have been traditionally recognised as a critical point of disagreement between the unquestionable sovereign rights of the states bordering the strait and the needs of freedom of movement of the states that navigate in them. ${ }^{3}$

As it is known, during the III Conference of the United Nations on the Law of the Sea Spain held a strong opposition to the establishment of a regime of transit passage applicable to straits used for international navigation, given the repercussions that this would bring for navigation and overflying in the Strait of Gibraltar and the restriction of Spain's competencies in this respect. ${ }^{4}$

In fact, the main reason by which Spain abstained in the vote on the Draft Convention on the Law of the Sea in April 1982 was the regulation established in Part III of the UNCLOS, and more specifically, in articles $38,39,4 \mathrm{I}$ and 42 , relating to the regime of transit passage. 5

Moreover, when Spain finally decided to sign this Convention on the $4^{\text {th }}$ December 1984 , the signature was accompanied by nine interpretative declarations, five of which were related to the transit passage regimen planned for certain straits used for international navigation (specifically the $2^{\text {nd }}, 3^{\text {rd }}, 4^{\text {th }}, 6^{\text {th }}$ and $7^{\text {th }}$. In spite of the fact that at the time of the ratification of the UNCLOS, on the $15^{\text {th }}$ January 1997, Spain did not maintain two of these last declarations (the $4^{\text {th }}$ and the $7^{\text {th }}$ ) and included in the $3^{\text {rd }}$ declaration the essential parts of the other three (the $2^{\text {nd }}$, the $3^{\text {rd }}$ and the $6^{\text {th }}$ ), we can state that the essential core of the declarations formulated by Spain related to the UNCLOS refer to the regime of transit passage and its possible application to the Strait of Gibraltar, although of course, without questioning the right of transit passage. ${ }^{6}$

The ratification of the UNCLOS by Spain definitively resolved the application of the regime of transit passage in the Strait of Gibraltar, with all that this involves. On the other hand, it is clear that

\footnotetext{
2 Vid. J.M. Sobrino., 'La mar, un escenario abierto', in J.M. Sobrino (coord), Mares y océanos en un mundo en cambio: tendencias jurídicas, actores y factores. XXI Jornadas de la Asociación Española de Profesores de Derecho Internacional $y$ Relaciones Internacionales. A Coruña, 22-24 de septiembre de 2005 (Tirant lo Blanch, Valencia, 2007) at 28, for whom the evolution of the Law of the Sea has been developed and is still developed subject to the tension between the principles of freedom and appropriation.

A.G. López, La navegación por los estrechos: Geoestrategia y Derecho (Dykinson, Madrid, 2008) at 30.

4 A full analysis of the position of Spain in this respect can be seen in J. de Yturriaga, Ámbitos de soberanía en la Convención de las Naciones Unidas sobre el Derecho del Mar. Una perspectiva española (Ministerio de Asuntos Exteriores, Madrid, 1993) at 199-321.

5 As stated the Ambassador of Spain, Lacleta Muñoz. Vid. Third United Nations Conference on the Law of the Sea, vol. XVI, at I60, para. 99.

6 Vid. C. Jiménez, 'La ratificación por España de la Convención de 1982 sobre el Derecho del mar y del Acuerdo de 1994 sobre la aplicación de la Parte XI: nuevos riesgos de la codificación del Derecho internacional', 53 Revista Española de Derecho Internacional (200I) at 120.
} 
this Strait possesses all the defining characteristics (geographical, legal and functional) of straits used for international navigation in which transit passage is applied. Effectively, this is a natural passage which constitutes a contraction of the sea that separates two bodies of land and joins two areas of sea ${ }^{7}$ which make up part of the territorial sea of one or more states ${ }^{8}$ and which indisputably goes beyond the level of utility required for international navigation as it is a strait used extensively by ships and vessels of many states. In this sense, in 2012 for example, the ships transiting this Strait were about IIO.000, of which approximately 75\% were vessels transiting from east to west or vice versa and $25 \%$ were ferries and high speed craft covering the Strait between the ports of Algeciras, Tarifa, Ceuta and Tangier. ${ }^{9}$

And as we will see below, the application of the regime of transit passage in the Strait of Gibraltar implies, among other things, that the control of maritime traffic and more specifically the designation of maritime channels and the establishment of a traffic separation scheme in it, as well as its substitution, must be carried out in conformity with the specific procedure planned to this effect in article $4 \mathrm{I}$ of the UNCLOS.

\section{THE ORGANIZATION OF MARITIME TRAFFIC IN THE STRAIT OF GIBRALTAR}

A clear sign of the complicated balance between the interests of the states bordering the strait used for international navigation in which transit passage is applied and the user states of these straits is undoubtedly given by the regulation contained in article $4 \mathrm{I}$ of the UNCLOS as far as the establishment of the TSS in these cases is concerned. ${ }^{\text {IO }}$

In this sense, we must point out that the afore-mentioned article defines a more limited framework of action for the states bordering the strait than when this type of scheme is established in those spaces where innocent passage is applied, in accordance with that set out in article 22 of the UNCLOS.

Specifically, article 4I of the UNCLOS establishes that the states bordering those straits where transit passage is applied may designate sea lanes and establish the TSS, or substitute it, only when it is necessary for the safe passage of the ships, these lanes and schemes being subject to the generally accepted international regulations, ${ }^{\mathrm{II}}$ in contrast to that set out in article 22 of the UNCLOS that does

\footnotetext{
Vid. E. Brüel, International Straits. A Treatise on International Law (Sweet and Maxwell, London. I947), at I8-19.

8 It is not necessary the whole of strait waters make up part of territorial sea. Vid.D. Pharand, 'International Straits', 7 Thesaurus Acroasium(1977), at 66.

9 Information given by Centro de Coordinación de Salvamento Maritimo de Tarifa (on file with the autor).

ro Vid. V.L. Gutiérrez, 'Estudio del régimen jurídico del Estrecho de Gibraltar: conflictos de soberanía, espacios marinos y navegación', in A. Del Valle and R. El Houdaigui (dirs), Las dimensiones internacionales del Estrecho de Gibraltar Les dimensions internationales du Détroit de Gibraltar (Dykinson, Madrid, 2006), at. 282.

II Vid. A. López, supra n. 4, at 297-298. In our opinion Rule io of Convention on the International Regulations for Preventing Collisions at Sea (adopted 20 October 1972, entered into force I5 July 1977) is particularly relevant in this respect. As IMO highlights Rule ro states that ships crossing traffic lanes are required to do so "as nearly as practicable at right angles to the general direction of traffic flow." This reduces confusion to other ships as to the crossing vessel's intentions and course and at the same time enables that vessel to cross the lane as quickly as possible. Besides fishing vessels "shall not impede the passage of any vessel following a traffic lane" but are not banned from fishing. There is an exemption applied to vessels which are restricted in their ability to manoeuvre "when engaged in an operation for the safety of navigation in a traffic separation scheme" or when engaged in cable laying. In 1987 the regulations were amended. It was stressed that Rule
} 
not require for the TSS to be necessarily established to guarantee safety of navigation or that it be fully subjected to the generally accepted regulations.

Furthermore, for the designation or the establishment of these lanes and schemes in straits where transit passage is applied, the states must previously submit proposals to be adopted to this end to the competent international organization, and which in this case, as we know, is the International Maritime Organization (IMO). Furthermore, when we are dealing with a TSS that affects the waters of two or more states bordering the strait, as occurs in the case of the Strait of Gibraltar, these states must cooperate when formulating joint proposals to the IMO. This Organization can only adopt the sea lanes and the TSS in joint agreement with the afore-mentioned states. None of this is necessary in those spaces where innocent passage is applied.

Therefore, the establishment of the TSS in the Strait of Gibraltar, and its substitution, is conditioned by limits derived from this strait being qualified as a strait used for international navigation in which transit passage is applied in conformity with the UNCLOS. For this reason, first of all we will analyse the necessary cooperation between Spain and Morocco in the implementation of the TSS in the Strait of Gibraltar. Secondly, we will study the way in which the maritime traffic in the Strait of Gibraltar has been organized according to this scheme. Finally, we will analyse the mandatory ship reporting system that has been in place since 1997 within the TSS.

\section{(I) The cooperation between Spain and Morocco in the control of maritime traffic in the Strait of Gibraltar}

As we have just stated, neither Spain nor Morocco has the competence to adopt the TSS unilaterally, because it must be carried out by means of a joint proposal to the IMO, that is the competent body to proceed to its adoption in joint agreement with both states, and after which both states would be in conditions to establish or substitute, where necessary, the TSS.

This complex procedure, with the necessary three-way agreement, could initially seem the least advisable to implement a TSS in the Strait of Gibraltar as this is a space marked by territorial controversies and the absence of fixed maritime boundaries between the two states bordering the strait involved, Morocco and Spain. ${ }^{12}$ It could have been worse if the United Kingdom and the Gibraltar authorities themselves had played a more aggressive role in the defence of their interests in the area.

However, the establishment of the TSS in the Strait of Gibraltar has provided an opportunity for Hispano-Moroccan cooperation that, in our opinion, could be considered exemplary, due to its long

Io applies to traffic separation schemes adopted by the IMO and does not relieve any vessel of her obligation under any other rule. It was also to clarify that if a vessel is obliged to cross traffic lanes it should do so as nearly as practicable at right angles to the general direction of the traffic flow. Finally, in 1989 Regulation to was further amended to clarify the vessels which may use the "inshore traffic zone."

${ }^{12}$ In this respect, A. Del Valle, 'España-Marruecos: una relación bilateral de alto potencial conflictivo, condicionada por la Unión Europea - Panorama con propuestas', I4 Revista Electrónica de Estudios Internacionales (2007) at 5-6, highlights this absence of fixed maritime boundaries as one of the most problematic aspects in the relations between Spain and Morocco. 
path of four decades of existence ${ }^{\mathrm{r} 3}$ as well as to the absence of disagreements between both countries throughout all these years that the afore-mentioned TSS has been the object of diverse modifications.

Among these modifications, a special mention must be given to that adopted within the IMO Maritime Safety Committee in December $2006^{14}$, as a result of the new Tangier-Med port being brought into service. In the same way, we could stand out the modifications produced according to the Resolution MSC.300(87) of the afore-mentioned Committee, adopted on the I7 May 20I0 ${ }^{15}$, with the objective of changing the Mandatory Ship Reporting System after the entry into service in January 2010 of the Centre de Surveillance du Trafic Maritime de Tanger. Both will be analysed in more detail in sections 2 and 3 of this chapter.

The cooperation Hispano-Moroccan was increased with the adoption on 27 April $201 \mathrm{I}$ of an agreement between Tarifa and Tangier Vessel Traffic Services on Operational Procedures about interchange and share information related to maritime traffic, safety, marine environment and weather. ${ }^{16}$

Effectively, beyond the collaboration between both Centres in the application of the Mandatory Ship Reporting System, which will be analysed in more detail in section 3 of this chapter, the interchange of information also refers to other issues of maritime traffic.

For instance, in the scope of maritime safety this agreement establishes that the information obtained by one of the Centres about concentration of fishing vessels, vessels restricted in her ability to manoeuvres, or vessels not under command, among others, will be communicated by the appropriate way to the other Centre and, if considered necessary, included in their scheduled broadcasts.

Moreover, the Operational Procedures provides for the interchange of information obtained by one of the Centres in executing their functions in search and rescue or in operations related to environment in the coverage area when it may affect the area of the another Centre.

This cooperation, however, is conditioned by the application of the regime of transit passage in the Strait of Gibraltar. The possibility of the underwater navigation of submarines has a particular relevance in this respect, given that this type of navigation is not in theory included in these TSS.

As the doctrine has shown, this represents an obvious danger for the safety of navigation ${ }^{17}$ as it ostensibly makes the control of traffic of these submarines difficult in straits when they do not navigate on the surface, independently of whether the coastal state has the means available to detect their passage when they travel underwater, taking into account that even in these cases it is impossible

\footnotetext{
I3 Vid. T. Atmane, España y Marruecos frente al Derecho del Mar (Netbiblo, La Coruña, 2007), at 88.

${ }^{14}$ Doc. COLREG.2/Circ.58, II December 2006, text available electronically at <http://www.imo.org/blast/blastDataHelper.asp?data_id=I6759\&filename=58.pdf $>$, accessed 3I October 2014.

is Doc. MSC 87/26/Add.I, Annex 19, text available electronically at <http://www.imo.org/blast/blastDataHelper.asp?data_id=29322\&filename=300(87).pdf>, accessed 3I October 2014.

${ }_{16}$ The text of this agreement is available at A. Del Valle and J.D. Torrejón (eds), España y Marruecos: Tratados, Declaraciones y Memorandos de Entendimiento (I99I-20I3) (Servicio de Publicaciones de la Universidad de Cádiz, 20I3), at 417-422.

${ }_{17}$ Vid., among others, R. Riquelme, España ante la Convención sobre el Derecho del Mar. Las declaraciones formuladas (Universidad de Murcia, 1990), at 90-93; J. Verdú, "Derecho Internacional y protección del medio ambiente en el área del Estrecho de Gibraltar", in A. Del Valle and R. El Houdaigui (dirs), supra n.II, at 2 Io.
} 
to determine their nationality with total precision $^{18}$ and therefore the necessary measures established to this effect by the UNCLOS cannot be taken. Obviously, this danger gets worse in the case of the Strait of Gibraltar taking into account that neither Spain nor Morocco doesn't seem to have these means of detection.

Another relevant conditioning for the effective control over navigation in this Strait is the impossibility of suspending transit passage according to that set out in article 42.2 of the UNCLOS, which evidently limits the measures that Spain or Morocco can take in the case of a ship failing to

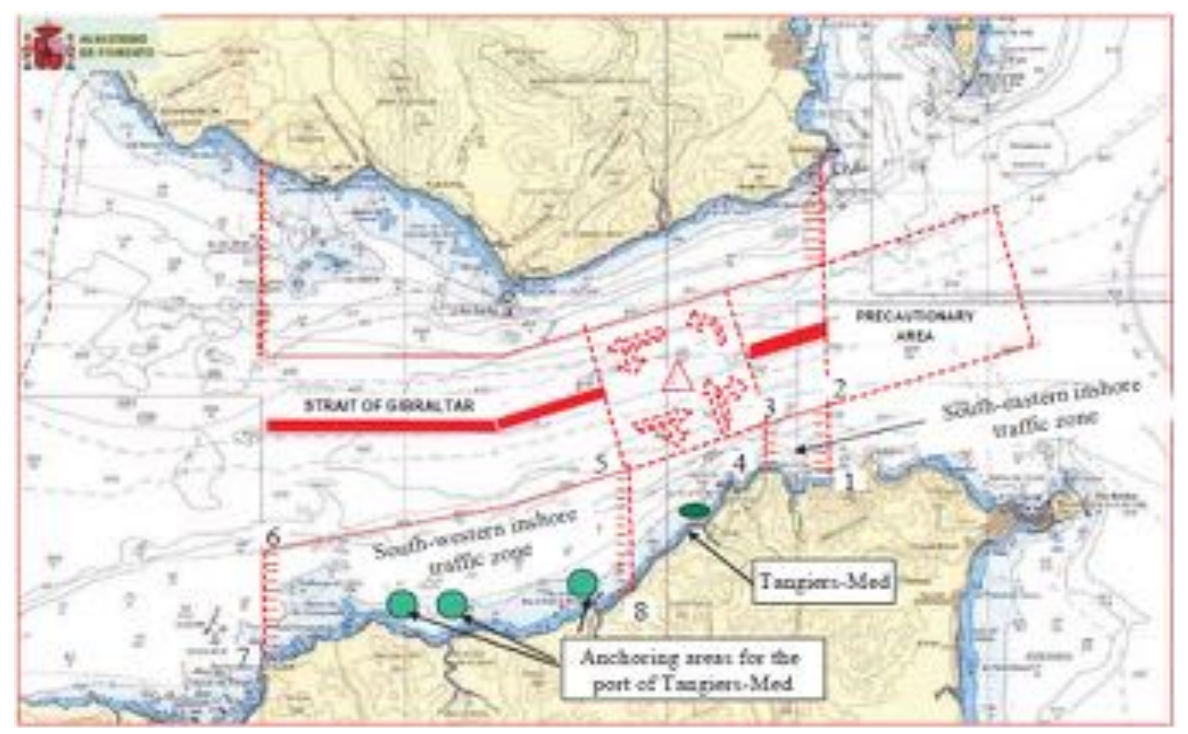
comply with any of its obligations whilst exercising its right to this aforementioned transit passage.

Nonetheless, it must be noted that article 233 of the UNCLOS precisely contemplates among the limited enforcement powers that the states bordering the strait used for international navigation have, the possibility that these states take "appropriate enforcement measures" when a foreign ship, that is not a warship or in the service of a state, commits a breach of its laws and regulations related to navigational safety and the regulation of maritime traffic, or the prevention, reduction and control of pollution by giving effect to the applicable international regulations in terms of dumping hydrocarbons, oil and other noxious substances in the strait. In order that the coastal state can apply these enforcement measures, the offence committed by the foreign ship must cause or threaten to cause serious damage to the marine environment of this strait.

As a result of this, in the case that a foreign ship which is not a warship or in the service of a state commits an offence regarding the applicable TSS regulations in the Strait of Gibraltar that causes or threatens to cause serious damage to the marine environment, both Spain and Morocco could take appropriate enforcement measures against this ship, which could involve, in our opinion, the suspension of the right of transit passage in accordance with that established in article 220.2 of the UNCLOS. ${ }^{19}$

ז8 Vid. V. Bou, La navegación por el mar territorial, incluidos los estrechos internacionales y las aguas archipelágicas, en tiempos de paz (Colegio de Oficiales de la Marina Mercante Española, Madrid, 1994), at 167.

I9 In this sense vid. V. Carreño, La protección internacional del medio marino mediterráneo (Universidad de Alicante, 1999), at 194; R. Riquelme, supra n. 16, at 162-166. 


\section{(2) The Traffic Separation Scheme in the Strait of Gibraltar}

As we can see in picture $I^{20}$ the TSS in the Strait of Gibraltar is made up of a navigation area adjacent to the Spanish coastline (northern coastal navigation area), a sea lane with a width of 2 nautical miles that must be used by ships coming out from the Mediterranean Sea and cross the Strait towards the Atlantic Ocean, a traffic separation area with a width of half a mile, another sea lane of between two and three miles in width that is used to cross the Strait from the Atlantic Ocean towards the Mediterranean Sea, two Precautionary areas (one on the east side of the TSS and the other in front of the Tangier-Med port, with recommended directions of traffic flow for ships arriving or setting sail from this port) and two coastal navigation areas (south-western and south-eastern navigation areas) adjacent to the African coast, with an area of free-navigation between them.

In particular, the two Precautionary areas and the division of the navigation areas adjacent to the African coast were introduced as a result of the modification of the TSS made in 2006, mentioned in the previous section and implemented on I July $2007^{21}$, fundamentally as a result of the Tangier-Med port entering into service and the expected important increase of maritime traffic coming from or going to this port. This would predictably cause numerous situations of crossing among ships entering and departing from this port and those passing through the TSS in transit.

Besides, the intention was to avoid conflictive situations, from the point of view of the safety of maritime traffic, that were arising between traffic entering or leaving the Bay of Algeciras and its interaction with the traffic crossing the Strait, as this was giving rise to frequent situations of two or more ships getting too close to each other in the area situated to the south of this bay.

Together with the density of traffic caused by the aspects discussed in the previous paragraphs, there were also the presence of a large fishing fleet and numerous recreational vessels in the waters of the Strait, as well as the peculiar meteorological and oceanographic characteristics of this area.

The objectives pursued with these modifications were, on one hand, to encourage the captains of the ships crossing the Strait of Gibraltar and their crews to take special precautions and to improve maritime safety, navigation and the protection of the marine environment of this space. And on the other hand, to prevent ships heading for the Tangier-Med port from crossing the coastal navigation area, thereby avoiding ships crossing in close proximity as was happening on the eastern side, as well as stopping these ships from heading directly for the port without using the separation lanes.

\section{(3) The Mandatory Ship Reporting System}

Another notable aspect of the TSS in the Strait of Gibraltar is the Mandatory Ship Reporting System implemented on the $3^{\text {rd }}$ June 1997, in accordance with Resolution MSC.63(67) of the IMO Maritime Safety Committee adopted on the $3^{\text {rd }}$ December 1996, and modified by Resolution MSC.300(87) of the afore-mentioned Committee adopted on the $17^{\text {th }}$ May 2010. ${ }^{22}$ This last modification was produced as a consequence of the start up in 2010 of the Centre de Surveillance du Trafic Maritime de Tanger (TANGIER TRAFFIC), which since the $\mathrm{I}^{\text {st }}$ December 2010 shares the work of receiving reports with

\footnotetext{
20 Source: International Maritime Organization (Doc. NAV 52/3/2).

21 Supra n. I4.

${ }^{22}$ Supra n. 15.
} 
the Centro de Coordinación de Salvamento Maritimo de Tarifa (TARIFA TRAFFIC), which until that time had been carrying out this work alone.

It was precisely in this last modification of the TSS when the United Kingdom took an explicit stance by declaring their reticence over it and pointing to their interests in the area due to their presence in Gibraltar ${ }^{23}$, although as we have just mentioned, Resolution MSC.300(87) was finally adopted with no further difficulties.

The fundamental objective of the mandatory ship reporting system is to facilitate the exchange of information between ships and the coast, in the interests of safe navigation and protection of the marine environment.

In accordance with that set out in paragraph I.I of the Annex to Resolution MSC.300(87), the following categories of ships have the obligation to participate in the reporting system: a) all ships of 300 tonnage and over; b) all ships, regardless of gross tonnage, carrying hazardous and/or potentially polluting cargo, as defined in paragraph I.4 of the Guidelines and criteria for ship reporting systems (Resolution MSC.43(64)); c) ships engaged in towing or pushing another vessel regardless of gross tonnage; d) any category of vessel less than 300 gross tonnage which is using the appropriate traffic lane or separation zone in order to engage in fishing; and e) any category of ships less than 300 gross tonnage which is using the appropriate traffic separation zone in an emergency in order to avoid immediate danger.

The ship's report must contain the necessary information to carry out the objectives of the system, specifically, the name of the ship, call sign and IMO identification number; the date and time of even; the position in latitude and longitude or true bearing and distance from a clearly identified landmark; true course; speed in knots; port of departure; port of destination and expected time of arrival; cargo and quantity, and if dangerous goods are on board their IMO classes and quantity; defect, damage and/or deficiencies affecting the structure, cargo or equipment of the ship, or any other circumstances affecting normal navigation; the address for provision of information concerning a cargo of dangerous goods; the total number of persons on board; the estimated quantity of bunker fuel and characteristics for ships carrying over 5.000 tonnes bunker fuel; and the navigation conditions. $^{24}$

The ship's report, with the abbreviated title "GIBREP", will be sent to TARIFA TRAFFIC or TANGIER TRAFFIC depending on where they come from, so ships coming from the Mediterranean must report their movements to TARIFA TRAFFIC and those coming from the Atlantic must report to TANGIER TRAFFIC.

More specifically, ships going west must report to TARIFA TRAFFIC when they cross the meridian $005^{\circ} 15^{\prime}, 00 \mathrm{~W}$, and ships going east must report to TANGIER TRAFFIC when they cross the meridian $005^{\circ} 5^{\prime}, 00 \mathrm{~W}$.

23 Vid. S. Díaz, "Régimen jurídico del control del tráfico marítimo en el Estrecho de Gibraltar", in J. Benamar and J.J. Fernández, La gestión pública fronteriza en el Estrecho de Gibraltar (Ifzarne, Tanger, 20I), at 255.

24 Vid. para. 3.2 of Annex of Resolution MSC.300(87). 
Furthermore, ships leaving the limits of a port or anchorage must report to the nearest of the two coastal stations, except for those ships leaving the Tangier-Med port and its anchoring areas, which must always report to TANGIER TRAFFIC.

Bearing in mind that the ferries that regularly cross the Strait of Gibraltar generally follow published timetables, the possibility of adopting special individual agreements on reports from these ferries is established, subject to approval from TARIFA TRAFFIC and TANGIER TRAFFIC.

Given the latter, and in accordance with that set out in the agreement signed in $201 \mathrm{I}$ on communications and exchange of information between both Centres, a procedure has been set up so that those ferries and high speed craft (HSC) that regularly connect the ports on both sides of the Strait are subject to special regulations, in such a way that the identification and monitoring for statistical reasons carried out by TARIFA TRAFFIC and TANGIER TRAFFIC distinguish between the ships with GIBREP reports and the ferries and HSC that cross the Strait.

Finally, it must be noted that both Centres are in permanent contact via a telephone line and that they share, in real time, information relative to the ships that have reported to one of the Centres and that subsequently navigate through waters corresponding to the other. This undoubtedly results in a greater and more efficient guarantee of navigational safety in the Strait of Gibraltar, especially if we also bear in mind that the agreement signed in $201 \mathrm{r}$ stipulates the procedure to be followed in order for one of the Centres to assume the supervision of all of the maritime traffic in the waters of the Strait and to receive reports from all of the ships is transit in the area in the case of one of the Centres becoming unexpectedly inoperative due to a breakdown or for maintenance requirements. ${ }^{25}$

\section{CONCLUSIONS}

As we have seen throughout this study, the consideration of the Strait of Gibraltar as a strait used for international navigation where the right of transit passage is applied, in accordance with that set out to this end in the UNCLOS, has conditioned the configuration of the TSS in this Strait and has marked the limits within which the states bordering this strait, Spain and Morocco, have had to act to this effect.

Nonetheless, in spite of the added complexity that may have been caused by this afore-mentioned scheme having to be developed within the framework of a regulation that requires constant agreement between both states and a three-way coordination, due to the TSS having to be necessarily adopted within the IMO, the truth is that, in our opinion, this has led to a model scene of Hispano-Moroccan cooperation, with no notable disagreements in the forty years of existence of the TSS in the Strait of Gibraltar.

In this sense, we must remember that the TSS has been the object of various modifications, that have always derived from joint proposals from Spain and Morocco, among which we can highlight that one carried out in 2007 caused by the entry into service of the Tangier-Med Port, or that relating to the modification in 2010 of the Mandatory Ship Reporting System with the aim of distributing the

\footnotetext{
${ }_{25}$ As it is established in para. 8.3 of Annex of Resolution MSC.300(87).
} 
reports between the Tarifa and Tangiers Maritime Traffic Control Centres, once the latter started functioning on the $\mathrm{I}^{\text {st }}$ December 2010.

This cooperation was increased with the adoption in 201 of an agreement between those Centres about interchange and share information related to maritime traffic, safety, marine environment and weather.

Certainly this model practice is influenced, on one hand, by the fact that this cooperation is compulsory, in accordance with that set out in article $4 \mathrm{I}$ of the UNCLOS, given that in the case of straits used for international navigation where the right of transit passage is applied, the states bordering the strait can only establish schemes that have been adopted by the IMO by means of a joint proposal from the states, and, on the other hand, due to the limited impact that territorial controversies between Spain and Morocco could have on this TSS, all of which has facilitated to a large extent this cooperation.

In any case, the experience of the TSS in the Strait of Gibraltar is, in our opinion, a reference point that deserves to be taken into account when evaluating the potential of a profitable cooperation between Spain and Morocco in areas of common interest for both states, leaving out the existing territorial claims. 